\title{
Study on Stability and Toxicity Test of the Antibacterial Substance NO.026- I
}

\author{
Li ZHANG ${ }^{1 *}$, Yong WANG ${ }^{1}$, Yu-bo WANG ${ }^{2}$, Ning YANG ${ }^{1}$, \\ Wen-jing XIA ${ }^{1}$, Jia-bo QU ${ }^{1}$, Yan $\mathrm{LI}^{1}$ \\ 1 University of Science and Technology Liaoning, Anshan 114051 P. R.China \\ 2 Shenyang Agricultural University, Shenyang, 110161 P. R. China \\ *Corresponding author: zI20040306113@163.com
}

Key words: Colletotrichum lycopersici , Antibacterial substance NO.026-I , Stability , Toxicity test Abstract: The antibacterial substance NO.026- I is obtained from Streptomyces avermitilis NO.026. It has significant antagonistic effect on Colletotrichum lycopersici. The stability test results showed that with the increase of temperature, the antifungal activity of active substance NO.026- I showed a downward trend, and the thermal stabilities are remarkable at room temperature. The active substance NO.026- I was relatively stable at $\mathrm{pH}$ 5. The $40 \mathrm{~W}$ light is more stable than bright light. It belongs to the high degree of photosensitive compounds and should be stored away from light. According to the Toxicological Testing Method for Pesticides (GB15670-1995), the results showed that the acute oral toxicity and the acute toxicity through skin of antibacterial substance NO.026-I on Kunming mice are in a low toxicity level. The antibacterial substance NO.026-I is mild irritation to the skin and the eyes of rabbits.

\section{Introduction}

With the development of the times, a lot of chemical pesticides have been applied to crops in the traditional agriculture to increasing production. But people gradually realize that their living environment has been seriously attacked by pesticide pollution [1]. For example, the problems are residue, resistance, resurgence and pollution. The researchers will look to seek safe biological pesticide to human health and ecological environment in order to ensure the effectiveness of agricultural sustainable development. Biological pesticide has become the research focus of great concern because of its characteristics of low toxicity and high efficiency, strong selectivity and the residual time is short, and environmentally friendly, in pesticide market share gradually expanded is enough to prove that it will become one of the most potential of this century "Chaoyang industry". It is one of the important ways to seek and explore natural bioactive substances from natural resources to prevent and eliminate diseases and insect pests in agricultural production. About 8000 kinds of antibacterial substances have been reported. $80 \%$ of them are produced by actinomycetes, while those isolated from natural substrates are only about $1 \%$ of the total actinomycetes [2]. Therefore, the study on the stability and toxicity test of antibacterial substances from actinomycetes secondary metabolites has important scientific significance, and is also the inevitable requirement of social development.

\section{Experimental}

\section{Materials}

Test sample. The antibacterial substance NO.026-I, by the University of Science and Technology Liaoning biological engineering laboratory of bio pharmaceutical technology room.

Test strain. Colletotrichum lycopersici, by the University of Science and Technology Liaoning biological engineering laboratory of bio pharmaceutical technology room.

Culture medium. PDA medium.

Test animals. Kunming mice, by the laboratory animal center of China Medical University. Japanese Big-ear rabbit, by the Shenyang Pharmaceutical University Test Center. 


\section{Methods}

The stability test. (1)The influence of temperature. Set up the ranks of temperature: $15^{\circ} \mathrm{C}, 25^{\circ} \mathrm{C}$, $35^{\circ} \mathrm{C}, 45^{\circ} \mathrm{C}, 55^{\circ} \mathrm{C}, 65^{\circ} \mathrm{C}, 75^{\circ} \mathrm{C}, 85^{\circ} \mathrm{C}, 95^{\circ} \mathrm{C}, 105^{\circ} \mathrm{C}$, thermostatically handle it for $30 \mathrm{~min}$ and $60 \mathrm{~min}$ [3]. Quote the solution of active substance NO.026-I which haven't been temperature treated to be CK. Using the filter paper method to determine the antimicrobial action against Colletotrichum lycopersici, These strains are cultured at $25^{\circ} \mathrm{C}$ for $72 \mathrm{~h}$ and the experiment is repeated for 3 times [4]. (2)The influence of pH. Set up the ranks of $\mathrm{pH}$ : 1.0, 3.0, 5.0, 7.0, 9.0, 11.0, 13.0, using 1mol/L $\mathrm{NaOH}$ and $1 \mathrm{~mol} / \mathrm{L} \mathrm{HCl}$ to control the $\mathrm{pH}$. The experiment is repeated for 3 times in the same way as before. (3)The influence of light intensity. Divide the experiment article into two parts, one of them lighted under the $40 \mathrm{~W}$ light for $12 \mathrm{~h}, 24 \mathrm{~h}, 36 \mathrm{~h}, 48 \mathrm{~h}, 60 \mathrm{~h}, 72 \mathrm{~h}$, put another part under the bright light for $12 \mathrm{~h}, 24 \mathrm{~h}, 36 \mathrm{~h}, 48 \mathrm{~h}, 60 \mathrm{~h}, 72 \mathrm{~h}$ [5]. The experiment is repeated for 3 times in the same way as before.

The toxicity test. Before the experiment, observe and docile the test animals for $7 \mathrm{~d}$, weight them with no food every day. Eliminating the natural death, make sure the rest of the mice are healthy. The bait is the bar, provide aseptic water for drinking. Put $0.1 \mathrm{~g}$ antibacterial active substance NO.026-I into $1 \mathrm{~mL}$ distilled water use for reserve. (1)Acute oral toxicity. Choosing the grown mice are four females and males in each group with 180 200g. Feed the drug form mouth. Before the test the mouse's stomach must be empty but they can drink water. The dosage of the drug depends on the weight of mouses $(10 \mathrm{~mL} / \mathrm{kg})$. And let them eat after $4 \mathrm{~h}, \mathrm{observing}$ them constently for $30 \mathrm{~min}$, after $1 \mathrm{~h}, 2 \mathrm{~h}, 4 \mathrm{~h}$ repeat the obvserving. And then repeat the observing everyday to lasting for 14 days, using the Horn's method to satistic the result [6]. (2)Acute percutaneous toxicity. Choosing the grown mice are five females and males in each group with 200 240 g. Regaring $2000 \mathrm{~mL} / \mathrm{kg}$ as the max dosage. Before the experiment, losing the hair of the back for $36 \mathrm{~cm}^{2}$, confirming that there is no damage to the skin, smearing the skin with antibacterial active substance NO.026-I , covering the area with gauze. Clean the area after $4 \mathrm{~h}$. After the test, observing and recording the symptoms of poisoning, the relief of the symptoms and the disapearing moments of poisoning. Observing them at least one each day to lasting for $14 \mathrm{~d}$, using the statistical test of Horn's method to statistic the result [7]. (3)Acute skin irritation. Choosing the rabbits are four females and males in each group with $2.2 \sim 2.6 \mathrm{~kg}$. Before the experiment, losing the hair of the back for $18 \mathrm{~cm}^{2}$, confirming that there is no damage to the skin, smearing the skin with $0.5 \mathrm{ml}$ antibacterial active substance NO.026-I to each one, covering the area with gauze. Clean the area after $4 \mathrm{~h}$. After the test, observing and recording. The other group is used as a control, observing the damage after $1 \mathrm{~h}, 24 \mathrm{~h}, 48 \mathrm{~h}$. (4)Eye irritation. Choosing the rabbits are two females and males in each group with $2.2 \sim 2.6 \mathrm{~kg}$. Quote the left eye to test. Drift the antibacterial active substance NO.026-I $0.1 \mathrm{~mL}$ for each one, passive closure for about $1 \mathrm{~min}$. The rabbits are observed the reaction after $1 \mathrm{~h}, 24 \mathrm{~h}, 48 \mathrm{~h}$. After $4 \mathrm{~d}$ and $7 \mathrm{~d}$, drift the sodium fluorescein is put into the eye to observe the corneal injury.

\section{Rresults and Analysis}

\section{The stability test.}

The influence of temperature. The results showed that the temperature has a great influence on the stability of the active substance NO.026-I. At low temperature, the stability of the active substance is better. After $35^{\circ} \mathrm{C}$, the stability will decrease with the increase of temperature. In addition, at the same temperature, the treatment time is different, and the stability of active substance NO.026- I will also have different degrees of influence. When treating 60min, the active substance will lose its activity after $85^{\circ} \mathrm{C}$. Therefore, the active substance is not heat resistant compound, it can be preserved at room temperature, and it should not be higher than $35^{\circ} \mathrm{C}$, and as is shown in the figure 1 . 


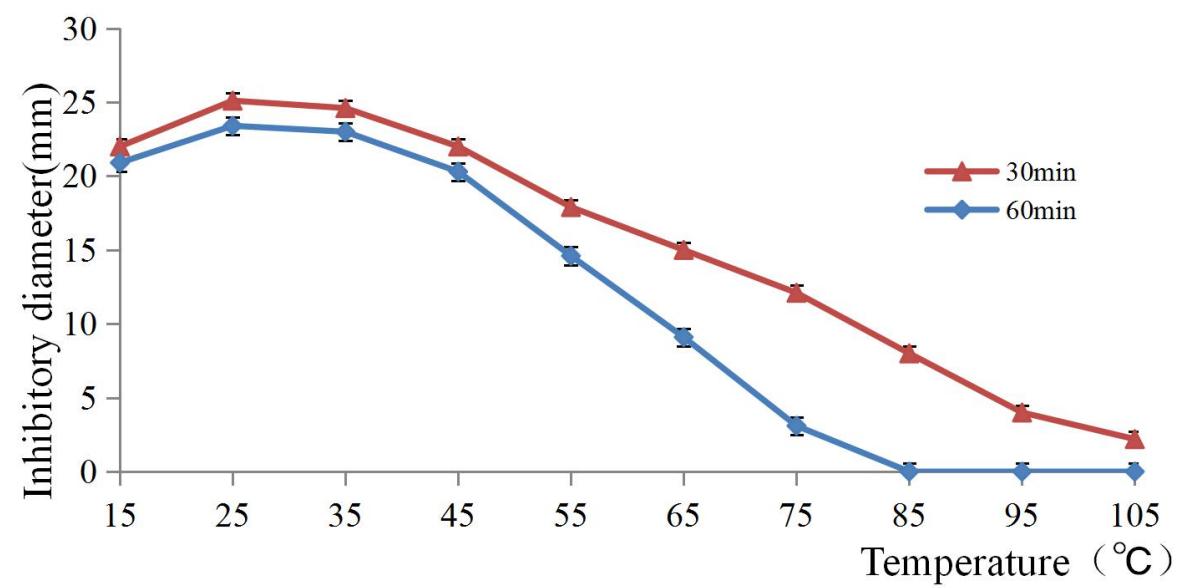

Fig. 1 Antifungal activity effect of the substance NO.026- I on Colletotrichum lycopersici at different treatment temperatures

The influence of $\mathbf{p H}$. The results showed that in acidic environment, the inhibitory activity of active substance NO.026- I decrease but not obvious, while it is relatively stable under weak acid condition, and the stability is best under the condition of $\mathrm{pH} 5$. With the increase of alkalinity, the stability of the active substance NO.026-I decrease greatly, indicating that the active substance is easily decomposed under the alkaline condition, and as is shown in the figure 2.

The influence of light intensity. The results showed that the antibacterial activity of the active substance NO.026-I almost no change, under the $40 \mathrm{~W}$ light for $12 \mathrm{~h}, 24 \mathrm{~h}, 36 \mathrm{~h}$, $48 \mathrm{~h}, 60 \mathrm{~h}, 72 \mathrm{~h}$, but under the bright light, the inhibitory activity will decrease with the increase of time, and its loss is obviously after $72 \mathrm{~h}$. Therefore, the antibacterial substance is highly photoreceptor and should be kept away from light, and as is shown in the figure 3 .

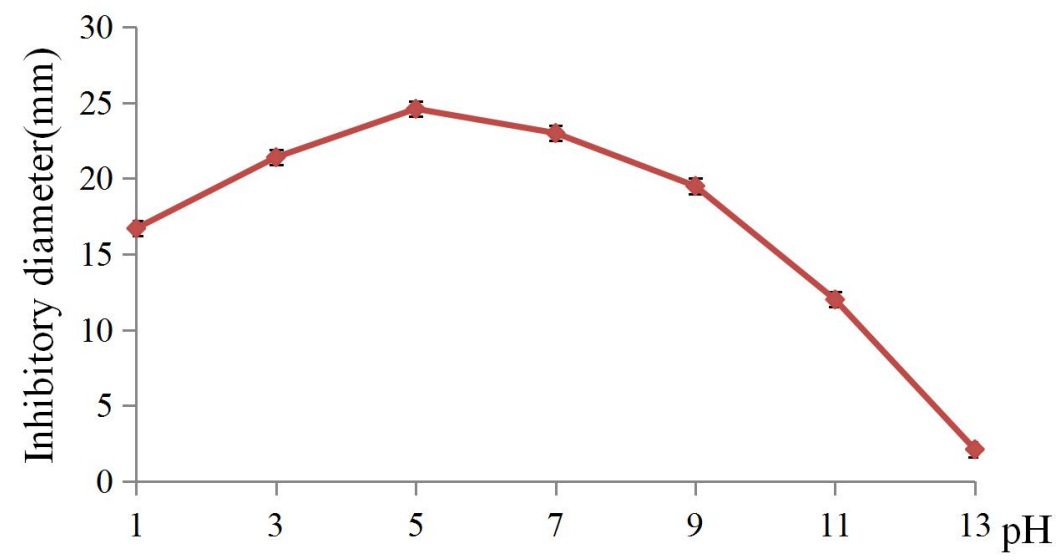

Fig. 2 Antifungal activity effect of the substance NO.026- I on Colletotrichum lycopersici at different treatment $\mathrm{pH}$

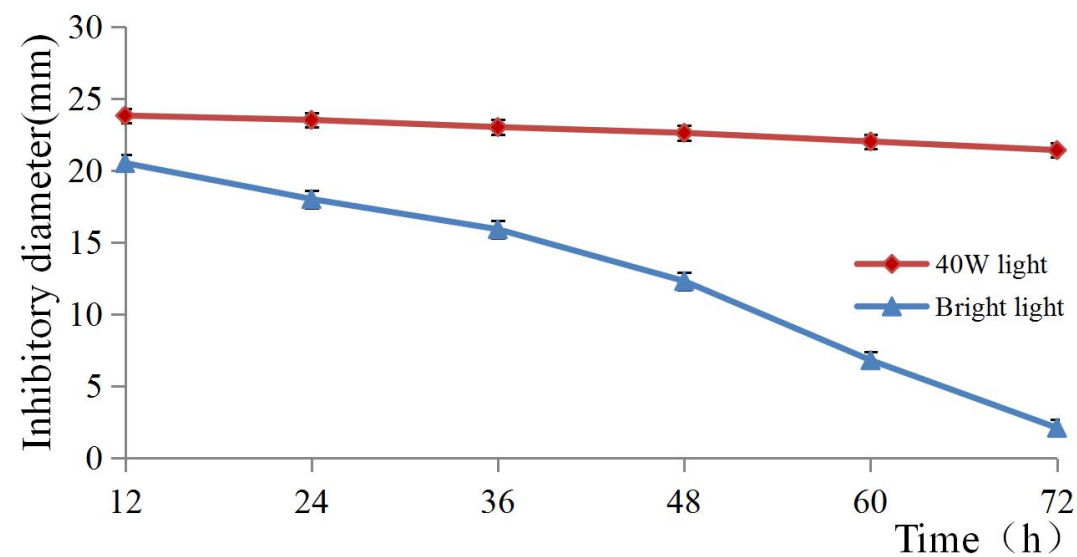

Fig. 3 Antifungal activity effect of the substance NO.026- I on Colletotrichum lycopersici at different illumination time 


\section{The toxicity test.}

Acute oral toxicity. The results showed that the mice in the high and medium dose group experienced tremors, convulsions, or even death after the administration of $1 \mathrm{~h}$. Most of the deaths occurred in $48 \mathrm{~h}$, and the survival mice are gradually restored to normal after $72 \mathrm{~h}$. In the low-dose group, the symptoms of poisoning are mild, and as is shown in the table 1. According to the Horn's method, the acute oral toxicity of female mouse $\mathrm{LD}_{50}$ is $2610 \mathrm{mg} / \mathrm{kg}$, and its $95 \%$ confidence is $1780 \sim 3830 \mathrm{mg} / \mathrm{kg}$. Male mouse $\mathrm{LD}_{50}$ is $1780 \mathrm{mg} / \mathrm{kg}$, and its $95 \%$ confidence is $989 \sim 3200 \mathrm{mg} / \mathrm{kg}$. According to the GB15670-1995, the acute oral toxicity of antibacterial substances NO.026- I is belonged to low toxicity level.

Table 1 Death number of different dose with antibacterial substances NO.026- I

\begin{tabular}{|c|c|c|c|c|c|}
\hline \multirow[b]{2}{*}{ Groups } & \multirow{2}{*}{$\begin{array}{c}\text { Dose } \\
\text { concentration } \\
(\mathrm{mg} / \mathrm{kg})\end{array}$} & \multicolumn{2}{|c|}{ Female } & \multicolumn{2}{|c|}{ Male } \\
\hline & & $\begin{array}{l}\text { Number of mice } \\
\text { in each group }\end{array}$ & $\begin{array}{c}\text { Death } \\
\text { Number }\end{array}$ & $\begin{array}{c}\text { Number of } \\
\text { mice } \\
\text { in each group }\end{array}$ & $\begin{array}{l}\text { Death } \\
\text { Number }\end{array}$ \\
\hline Low-dose group & 464 & 4 & 0 & 4 & 0 \\
\hline Mid- dose group & 1000 & 4 & 0 & 4 & 1 \\
\hline Mid-dose group & 2150 & 4 & 1 & 4 & 2 \\
\hline Mid-dose group & 4640 & 4 & 4 & 4 & 4 \\
\hline High-dose group & 10000 & 4 & 4 & 4 & 4 \\
\hline
\end{tabular}

Acute percutaneous toxicity. The results showed that the mouse are applied after $4 \mathrm{~h}$, both activity and feeding decreased, and gradually recovered to normal after $24 \mathrm{~h}$. When the dose is $2000 \mathrm{mg} / \mathrm{kg}$, the mice die after $14 \mathrm{~d}$. Indicating that $\mathrm{LD}_{50}$ of the antibacterial substances NO.026- I is greater than $2000 \mathrm{mg} / \mathrm{kg}$ in acute dermal toxicity. According to the GB15670-1995, the acute dermal toxicity of the antibacterial substance NO.026- I is low toxic.

Acute skin irritation. The results showed that in $1 \mathrm{~h}, 24 \mathrm{~h}$ and $48 \mathrm{~h}$, the skin of rabbits have different degrees of erythema and edema, and as is shown in the table 2. According to the evaluation of skin irritation intensity, the antibacterial substance NO.026- I is mild irritation to the skin.

Table 2 Integration result of skin irritation with antibacterial substances NO.026- I

\begin{tabular}{ccccccc}
\hline \multirow{2}{*}{ Number } & \multicolumn{2}{c}{$1 \mathrm{~h}$} & \multicolumn{2}{c}{$24 \mathrm{~h}$} & \multicolumn{2}{c}{$48 \mathrm{~h}$} \\
\cline { 2 - 7 } & Erythema & Edema & Erythema & Edema & Erythema & Edema \\
\hline 1 & 2 & 2 & 2 & 2 & 2 & 1 \\
2 & 1 & 1 & 1 & 1 & 1 & 1 \\
3 & 0 & 0 & 1 & 0 & 1 & 0 \\
4 & 1 & 0 & 2 & 1 & 2 & 1 \\
\hline
\end{tabular}

Eye irritation. The results showed that the cornea and conjunctiva are damaged in different degrees after the rabbit eye drops into the antibacterial substances NO.026- I, with slight damage to the iris of individual eyes, and as is shown in the table 3. The maximum number of I.A.O.I is 43. The average of M.I.O.I. for $1 \mathrm{~h}, 24 \mathrm{~h}, 48 \mathrm{~h}, 72 \mathrm{~h}, 96 \mathrm{~h}$ and $168 \mathrm{~h}$ are respectively $11.0,34.3,29.3,27.0$, 22.3 and 13.5. According to the GB15670-1995, the antibacterial substances NO.026- I is mild irritation to the eyes. 
Table 3 Integration result of eyes irritation with antibacterial substances NO.026- I

\begin{tabular}{|c|c|c|c|c|c|c|c|c|c|c|c|c|c|c|c|c|c|c|c|c|c|c|c|c|}
\hline \multirow{2}{*}{ Number } & \multicolumn{4}{|c|}{$1 \mathrm{~h}$} & \multicolumn{4}{|c|}{$24 \mathrm{~h}$} & \multicolumn{4}{|c|}{$48 \mathrm{~h}$} & \multicolumn{4}{|c|}{$72 \mathrm{~h}$} & \multicolumn{4}{|c|}{$96 \mathrm{~h}$} & \multicolumn{4}{|c|}{$168 \mathrm{~h}$} \\
\hline & A & B & $\mathrm{C}$ & $\Sigma$ & $\mathrm{A}$ & $\mathrm{B}$ & $\mathrm{C}$ & $\Sigma$ & $\mathrm{A}$ & $\mathrm{B}$ & $\mathrm{C}$ & $\Sigma$ & $\mathrm{A}$ & $\mathrm{B}$ & $\mathrm{C}$ & $\Sigma$ & $\mathrm{A}$ & $\mathrm{B}$ & $\mathrm{C}$ & $\Sigma$ & $\mathrm{A}$ & $\mathrm{B}$ & $\mathrm{C}$ & $\Sigma$ \\
\hline 1 & 0 & 0 & 8 & 8 & 20 & 5 & 14 & 39 & 10 & 0 & 12 & 22 & 10 & 0 & 10 & 20 & 5 & 0 & 10 & 15 & 0 & 0 & 8 & 8 \\
\hline 2 & 0 & 0 & 16 & 16 & 20 & 5 & 16 & 41 & 20 & 5 & 18 & 43 & 20 & 5 & 16 & 41 & 15 & 0 & 16 & 31 & 10 & 0 & 12 & 12 \\
\hline 3 & 0 & 0 & 10 & 10 & 5 & 0 & 16 & 21 & 0 & 0 & 14 & 14 & 0 & 0 & 14 & 14 & 0 & 0 & 10 & 10 & 0 & 0 & 12 & 12 \\
\hline 4 & 0 & 0 & 10 & 10 & 20 & 0 & 16 & 36 & 20 & 0 & 18 & 38 & 15 & 0 & 18 & 33 & 15 & 0 & 18 & 33 & 10 & 0 & 12 & 22 \\
\hline
\end{tabular}

\section{Conclusion and Discussion}

After agricultural antibacterial compounds used in the field, it will enter the surface water, groundwater, soil, plant and air environment in different areas, protect the environment and maintaining the ecological balance is indispensable to pesticide use and development of the evaluation index. The study is to develop the 1 antibacterial substances from the aspects of environmental safety inspection, the results showed that the antibacterial activity of NO.026- I will decrease with the increase of antibacterial activity temperature, and room temperature stability is good. The $\mathrm{pH}$ is relatively stable under the weak acidity of 5.0. It belongs to highly photosensitive compound, should be kept away from light. According to the Toxicological Testing Method for Pesticides (GB15670-1995), the acute oral toxicity and the acute toxicity through skin of antibacterial substance NO.026- I on Kunming mice are in a low toxicity level. The antibacterial substance NO.026- I is mild irritation to the skin and the eyes of rabbits. It will be developed as a fungicide for application.

\section{References}

[1] Basch EM, Servoss JC, Tedrow UB: Safety assurances for dietary supplements policy issues and new research paradigms [J]. J Herb Pharmacother, 2005, 5: 3-15.

[2] Furumai, T., Yamakawa, T., Yoshida, R., Y., Igarashi. Clethramycin, a new inhibitor of pollen tube growth with antifungal activity from Streptomyces hygroscopicus TP-A0623 [J]. J Antibiotics, 2003, 56: 700-704.

[3] Ling-ling ZHANG, Mei-yu DONG, Feng-chun XU, et al. Study on Screening of Actinomyces C3- $\Pi$ and Stability of Fermentation Broth [J]. Modern Agricultural Science and Technology, 2009(3): 109-110.

[4] Jin-ju PAN, Ting YU, Yu-ke SHANG, et al. Inhibitory Activity and Identification of Biocontrol Bacteria BMP-11 against Pythium meliloti [J]. Acta Phytophylacica Sinica, 2008, 35(4): 311-316.

[5] Hai-bo JIANG, Wen-jing XU, Qian DU, et al. Inhibitory Activity and Stability from fermentation broth of BPS28 [J]. Journal of Jilin Agricultural Sciences, 2009, 34(1): 14-16.

[6] Shin IS, Yu YB, Seo CS, Ha HK, Lee MY, Huang DS, Kim JH, Shin HK: Subchronic toxicity of Sipjeondaebo-tang (SDT) in Sprague-Dawley Rats [J]. Regul Toxicol Pharmacol, 2011, 59: 375384.

[7] Kusunose M, Qiu B, Cui T, Hamada A, Yoshioka S, Ono M, Miyamura M, Kyotani S, Nishioka Y: Effect of Sho-saiko-to extract on hepatic inflammation and fibrosis in dimethylnitrosamine induced liver injury rats [J]. Biol Pharm Bull, 2002, 25: 1417-1421. 